\title{
THEORIZING THE RISE OF MICROENTERPRISE DEVELOPMENT IN CARIBBEAN CONTEXT
}

\author{
Marina Karides \\ Department of Sociology \\ Florida Atlantic University \\ mkarides@fau.edu
}

\begin{abstract}
Throughout the world development agencies and governments promote micro-enterprise development as a solution to the employment crisis and penury of the global south. But what brought about the unprecedented expansion and worldwide promotion of micro-enterprise development? As a case study on micro-enterprise expansion in the Republic of Trinidad and Tobago, this paper offers a grounded theory analysis based on semi-structured interviews with national and international officials active in micro-enterprise development. Themes drawn from the interviews demonstrate that the failure of past development policies and the neo-liberal response to these failures help explain why micro-enterprise development expanded vastly in Trinidad and Tobago. Theoretically, I draw from Luxembourg's (1951) and Nash's (1990) studies on subsistence or petty production under capitalism and the world-systems analysis of households (Wallerstein and Scott 1992a; 1992b) to develop a conceptual framework for understanding the expansion of micro-enterprise development under neo-liberalism globally. In this era, micro-enterprise development reflects two separate strategies of dealing with economic crises-informal or unwaged work and government transfer or social safety nets-merged into one.
\end{abstract}

\section{INTRODUCTION}

Throughout the globe development agencies promote micro-enterprises as an ideal solution to the employment crisis and penury of the global south (Isserles 2003; Itzigohn 2000; Johnson and Kidder 1999; Mosley and Hulme 1998; Dignard and Havet 1995; Grosh and Somolekae 1996; Rakowski 1994). Identified as a "hysteria," or a "revolution" of development (Gulli and Berger 1999), the unprecedented growth of micro-enterprise development is noted most in popular business magazines and specialty development journals.

Despite the rapid expansion of micro-enterprise programs there has been limited sociological investigation as to why micro-enterprise programs have captivated a host of development actors including the United Nations, governments, banks, non-governmental organizations, corporations and transnational agencies. A theoretical model explaining the worldwide proliferation of micro-enterprise programs is missing from major American sociology 
journals ${ }^{1}$ and the sociological literature generally. This absence is striking, not only due to the upsurge of micro-enterprise programs in the last twenty years, but also because of the previous attention these journals gave to Third World development strategies and their recent attention to globalization. World-systems, dependency and dependent development theorists, modernization proponents and others presented analyses and engaged in debates on development subjects such as the impact of foreign investment and industrialization (Dixon and Boswell 1996; Firebaugh 1996; Muller 1989,1985; Bollen 1983); income inequality and development (Korzeniewicz and Moran 1997; Nielson and Alderson 1995; Peacock, Hoover, and Killian 1988; Stack 1978); and urbanization (London and Smith 1988, Bradshaw 1987, Kentor 1981). As a latest strategy of economic development, micro-enterprise programs warrant similar attention and interrogation from the political economic perspective as that given to previous modes of "Third World" development.

\section{Definitions and Context: Micro-enterprises in Trinidad}

Micro-finance, micro-credit, and micro-enterprise development refer to governmental, nongovernmental, and private programs, international and national agencies, and banks and credit unions that lend small sums - from 50 dollars or less to 5,000 dollars or more - to individuals that are engaged or plan to engage in very small self-sustaining businesses that may operate as part of the formal or informal sectors. I prefer micro-enterprise development as opposed to micro-finance because it encapsulates the additional activities, such as "entrepreneurial training" and "savings skills," that agencies purportedly offer to micro-finance borrowers.

Micro-enterprise programs generally target self-employed or micro businesses (less than ten employees) that function as part of the informal sector including small production units, street vendors, and transportation service engaged in undocumented and unregulated economic activity (Johnson and Kidder 1999; Mosley and Hulme 1998; Grosh and Somolekae 1996). While women's self-started income generating projects may have been the original target of microenterprise development programs, most of Trinidad's current programs are gender neutral, although women are more likely than men (and this appears to be the trend globally) to use these programs (Grasmuck and Espinal 2000; Ehlers and Main 1998; International Labour Organization 1998).

Micro-enterprise programs engage in a wide variety of credit schemes. For instance, the Grameen Bank in Bangladesh, an early player and model for micro-lending programs, organizes women into groups of five persons in which two women are provided loans. Once these women have completed repayment, another set of women are permitted to borrow. The group is therefore implicated in the responsibility of repayment for each borrower. Other programs require borrowers to provide persons willing to sign as co-borrowers and/or provide some form of collateral such as a refrigerator. Some government micro-enterprise programs offer to secure the

\footnotetext{
${ }^{1}$ Including the American Journal of Sociology, American Sociological Review, Social Problems, and Social Force. Gender and Society has published articles on relationships between gender and micro-enterprises (Kantor 2002; Grasmuck and Espinal 2000; Ehlers and Main 1998). Portes, Guarnizo, and Haller (2002) examine the transnational network of micro-entrepreneurs but not the policy implication of microenterprise programs. Although related, much of the informal sector literature predates the promotion of the informal sector as an economic development solution in the form of microenterprises.
} 
borrower. More micro-enterprise programs, however, are beginning to function as banks and give direct loans to a person who is independently responsible for repayment of the loan. In these cases, there is often a loan officer with an income that is dependent on the repayment of the loan. One of the economic leaders in the Caribbean, Trinidad and Tobago promotes itself as "a nation of entrepreneurs" and relies on the advancement of micro-entrepreneurs and small businesses to overcome the nation's problems with poverty and unemployment (International Labour Organization 1995, Ministry of Development 1996). Trinidad and Tobago, a former Spanish and British colony gained independence in 1962. Unlike other Caribbean nations, Trinidad and Tobago benefits from petroleum and natural gas resources. Yet a large percent of the earnings from this sector are exported abroad and few (about 5 percent) employment opportunities for Trinidadians and Tobagonians exist in the business of energy production that provides 40 percent of the nation's GDP (CIA 2008). Despite this seemingly favorable economic positioning in relation to the remainder of the Caribbean, Trinidad and Tobago's unemployment (about 10 percent) and poverty rate (about 20 percent) remains similar to other English speaking Caribbean nations.

While micro-enterprise development is being implemented in almost every nation of the global south it seems to hold a special appeal to rentier states such as Trinidad and Tobago. The majority of Trinidad and Tobago's micro enterprise programs are government sponsored, many with the assistance of funds from the World Bank, the International Labour Organization (ILO) and the United Nation's Development Programme (UNDP). These organizations have regional offices in Trinidad and sponsor programs throughout the Caribbean. Nationally based private institutions, including banks and religious organizations, also engage in micro-enterprise development.

Initiated by non-governmental organizations (NGOs) as a form of social assistance for women in the global south, growing micro-enterprises is now an economic development strategy. Along with large-scale industrial development (and sometimes in lieu), governments' also implement micro-enterprise program to increase the rate of economic growth. Supporters of micro-enterprise development suggest that micro-enterprises can grow into larger successful businesses that may be able to link up with larger domestic or foreign capital firms. Others look to micro-enterprises for creating employment opportunities through an increase in the number of micro-enterprises or by micro-enterprises expanding and requiring additional employees. Finally, government leaders in Trinidad and Tobago have suggested that micro-enterprises will lead to economic growth as they become competitive in the international trade arena.

As a case study on micro-enterprise expansion in the Republic of Trinidad and Tobago, this work offers a grounded theory analysis (Glazer and Strauss 1967) of the expansion of this internationally lauded development strategy. The analysis provided here examines government officials and development professionals' perspectives of how the overwhelming tide of microenterprise development hit the shores of the Caribbean. It is not a study of the effectiveness of micro-enterprises, for instance by determining under what circumstances they offer an opportunity for survival or an opportunity for economic growth. Nor does the data collected permit an assessment of whether micro-enterprise are necessary for development. Rather, the paper offers an incipient frame for explaining the fast and vast expansion of micro-enterprise development.

With few exceptions the sociological literature has not linked discussions of the informal sector with the phenomenon of micro-enterprise development (Osirim 2009, Jurick 2004, 
Itzigsohn 2000; Rakowski 1994 are some exceptions). Broadly, studies of the informal sector have focused on determining its links with the formal sector (Light 2004; Waldinger and Lapp 1993; Portes and Sassen-Koob 1987), estimating the size of its expansion and relationship to the global restructuring (Freeman 2000; Waldinger and Lapp 1993; Castells and Portes 1988; Portes and Sassen 1987), and analyzing it as a gendered phenomena (Jurick 2004, Harrison 1991; Fernandez-Kelly and Garcia 1985; Barrow 1986). The political influence of informal sector workers in urban centers has garnered attention from sociologists (Cross 1998; Tripp 1997).

Although there is some recognition that the informal sector has mutated "from a problem of development into a solution for development" (Itzigsohn 2000; Poster and Salime 2000; Rakowski 1994; Tokman 1989), this paper provides an empirically grounded study of the phenomenon in Port of Spain, Trinidad and explains why micro enterprise development came to prominence in the mid-eighties ${ }^{2}$. I consider how informal micro-enterprises once considered anathema to development became a major development solution for Trinidad and Tobago and the Caribbean region.

An analysis of semi-structured interviews with national and international officials active in micro-enterprise development demonstrates that the failure of past development policies and the neo-liberal response to these failures help explain why micro-enterprise development vastly expanded in Trinidad over the last twenty years. In addition to interviews, I collected and reviewed documents produced by each of the development programs from which interviews were gathered that added to my findings on the expansion of micro-enterprise development ${ }^{3}$. Theoretically, I draw from Luxembourg's (1951) and Nash's (1990) studies on subsistence or petty production under capitalism and the world-system analysis of households (Wallerstein and Scott 1992a; 1992b) to develop an original framework explaining the expansion of microenterprise development. Although based in the Caribbean context, this study may have general applicability due to the international and monolithic character of micro-enterprise development and the similar patterns of economic development framed by neo-liberalism in the Caribbean and some Latin American countries.

The next section reviews economic development in the Caribbean and presents a political economic critique. This is followed with the introduction of a theoretical frame for understanding micro-enterprise expansion. I then discuss the methods, present my findings drawn from my interviews with micro-enterprise professionals, and conclude with a broader discussion on the implications of micro-enterprise development in the world-system.

\footnotetext{
2 Although there are few publications on micro-enterprise development in sociology journals and development journals (World Development, Development Studies), business journals (The MicroEnterprise Journal) often visit the subject. Yet these articles generally do not offer theoretical investigations but address practical concerns such as appropriate implementation strategies and widening program access.

${ }^{3}$ While the grounded theory analysis presented here is based primarily on interviews conducted with micro-enterprise professionals, it is also informed by interviews (45) and surveys (130) I conducted with micro-entrepreneurs in Trinidad and Tobago. Although in interviews micro-entrepreneurs describe the government as "unable to provide jobs" or that "they [government] have no place for us to work" and offered various assessments of micro-enterprise programs and reasons for their promotion, I do not rely on these interviews for the analysis presented here because of micro-entrepreneurs' limited engagement in the decision making process of national development strategies.
} 


\section{MICROENTPRISES IN ECONOMIC DEVELOPMENT}

\section{Modernization and Caribbean Micro-entrepreneurs}

Under the modernization regime that dominated the post-colonial Caribbean, microentrepreneurs, originally referred to as petty producers, were deemed economically unviablesubsistence workers that existed outside the realm of economic development (Malaki 1996; Reddock 1994). Indeed for most modernization strategists small-scale informal enterprises were associated with pre-modern or traditional values and considered contraindicative of the progress identified with the modern, "Western," world (Geertz 1963; McClelland 1961). ${ }^{4}$ In diverse regions across the globe, newly independent nations were recommended the same development strategies.

Lewis (1954), a major actor in Caribbean regional development, specifically disregarded small-scale enterprises in favor of large industry and emphasized foreign investment as the key component to building Caribbean economies. Caribbean development relied on "industrialization by invitation": a process of wooing foreign capital towards regional investment with tax break incentives, state funded production facilities, and deregulated employment conditions. He considered foreign investment essential primarily for two reasons: first, the scale of industrialization necessary to modernize the Caribbean economy was beyond the means of the island nations, thus requiring along with government investment external sources of funding (Malaki 1996; Lewis 1954). Second, Lewis believed that exposure to foreign capitalists was necessary to acculturate local actors to the practice of business; the local private sector was considered limited in skills and capital and had no role to play in industrial development. The business and industry established by foreign capital would provide the necessary basis for future industry to develop via downward linkages. Quite contrary to the current stress international development agencies place on small local enterprises to solve problems like poverty and unemployment, past development strategists rejected and devalued these type of initiatives assuming foreign capital and culture to promote growth.

Lewis's schema, influential beyond the Caribbean, divided the post-colonial economies into two separate components: a) a traditional sector, consisting of informal small-scale enterprises that were not driven by expansion but largely produced to meet basic consumption needs, and b) a modern capitalist sector, primarily interested in the generation of profits (Malaki 1996). Because the modern capitalist sector would offer wages higher than the earnings available in the traditional sector, workers would eventually migrate from traditional or informal work to formal employment. Once the majority of workers were absorbed into formal employment, there no longer would be an "unlimited supply of labor" (Lewis 1954). Eventually, labor scarcity would drive up formal sector wages marking the "turning point" of economic advancement. The formalization of labor would increase the purchasing power of the population, lead to a reduction of inequality, and rapidly increase the rate of economic growth.

Unfortunately, Lewis's design for Caribbean development did not arrive. Foreign investment in Caribbean industrial development, outside of petroleum in Trinidad and Tobago

\footnotetext{
${ }^{4}$ Geertz argued for the debilitating role small informal enterprises play in economic development. He states, “. . . the trader is perpetually looking for a chance to make a smaller or larger killing, not attempting to build up a clientele or a steadily growing business” (Geertz 1963:35).
} 
and bauxite in Jamaica, was hardly forthcoming (McBain 2005). Rather than the formalization of the labor force, regionally post-colonial development is marked by overurbanization whereby the urban population grows faster than infrastructure and industry so that most workers either earn an income in the service sector, through informal means or are left perpetually seeking an income source (Davis 2006; Smith 1995; Timberlake and Kentor 1983; Roberts 1978).

\section{Development Disappointments and the Revised Role of Microenterprises}

Throughout the Caribbean and Latin American region, the 1980s told a similar story-with few exceptions nations that implemented the recommended modernization strategies were economically debilitated with debt and limited economic growth—marking it as the "lost decade" for development in the region. Although better off in terms of GDP per capita than its neighboring islands, Trinidad and Tobago also witnessed a rise in poverty, unemployment, and income inequality (Dookeran 1996; Girvan 1997). International development agencies greeted the economic suffering of citizens by reprimanding their governments and not directly confronting the misleading promises of modernization. Rather, the World Bank, the IMF, commercial financial institutions and US interests grouped together as the Washington Consensus, blamed the explosion of unemployed, underemployed, and informal workers in the Caribbean and Latin America on the state-led economic development they had once promoted (Keily 1998; McMichael 1996; Kenworthy 1995).

While modernization may have been a capitalist and politically driven program, the neoliberal policies prescribed in the wake of its failure gave transnational corporations immense power to shape national economies (Davis 2006; Sites 2002; Klack 1998; Portes 1997; McMichael 1996). Along with privatization and free trade, this includes the endorsement of an entrepreneurial culture and limiting government's role in employment creation, the provision of social services, and regulation. Nations not incorporating and promoting the capital-favoring ideas of neo-liberalism are threatened with exclusion from global economic integration. From the eighties onwards, neo liberalism or free market economics became the dominant paradigm for economic development endeavors (Fiss and Hirsch 2005).

Besides state blaming, policy makers have provided very little discussion on the failure of the modernization project to produce the kind of development it had envisaged. During its period of theoretical prominence modernization thought predicted that in a twenty to thirty year period post-colonial nations would achieve a level of development similar to advanced capitalist nations. While this prediction seems far-fetched now, policy makers assumed that the Third World would be catapulted forward through engagement with advanced capitalist nations. One of my concerns with the current fervor over micro-enterprise development is that it portends a similar outcome to modernization. The lack of any strong theoretical grounding or consideration of the historical role of micro-enterprises or discussion of their earlier notoriety makes the current advocacy of them as an economic cure all even more problematic.

Both critics and supporters of capitalist expansion into the global south initially identified small scale or subsistence workers as a liability to successful development. While Lewis (1954) and modernization thinkers generally expected these enterprises to disappear as workers entered into industrial employment, Marxists depended on it - wage workers were the foundation of the socialist revolution (Nash 1990; Mattera 1985). Economic survival outside the industrial sector was not examined as part of the relations of capitalist production and considered inimical to 
labor's resistance. Both modernizationists and Marxists overlooked the value of unwaged labor or the subsistence sector to capitalist development.

Early feminist scholarship on women's unpaid reproductive work has demonstrated best the oversight of the contribution of non-wage household labor to the accumulation of capital (Luxembourg 1951). Particularly among poor and low-income households women's reproductive duties are extended to ensuring the economic survival of their families. Feminists illuminated the economic contributions that women made to the household through their informal enterprises that were absent in quantitative labor force analyses and gendered conceptions of work (Prugle and Tinker 1997; Truelove 1990: Fernandez-Kelly and Garcia 1985). Subsistence labor and petty trade and production are examples of household strategies often utilized by women to make ends meet when formal wages are insufficient, absent, or unavailable, thereby subsidizing capital accumulation (Freeman 2000; Hsiung 1996; Harrison 1991; Mies 1986). The perpetuation of these types of non-wage strategies into modernity was captured theoretically as the "informal sector" (Portes and Benton 1983). Associated with highly exploitive labor conditions and the inability of capital to create formal job opportunities, the informal sector was evaluated as one of the major failures of development.

Over the last two decades independent informal workers began to garner positive attention by researchers, policy makers, and international institutions that once dismissed them. The change in nomenclature-the term "micro-entrepreneur" replaced terms like "informal worker," "subsistence provider," and "income-generation" or "petty producer"-encapsulates a revised conception of informal small-scale businesses by development professionals. That a group of workers previously perceived as the dregs of society or the result of failed policies have been recast as exemplars of development exhibits a complete conceptual overhaul of the role of informal petty producers and household survival strategies to economic development.

There are few explanations for understanding how, after decades of dismissal and neglect, microentrepreneurs were refigured as a solution to the poverty, unemployment, and limited economic growth in the global south. The productive capacity of micro-entrepreneurs may help explain the recent drive to assist them (Tokman 1989). Several studies, de Soto's (1989) in Lima, Peru most notably, document the capacity of micro-enterprise to generate economic growth. These "legalist" scholars argue that although neglected (Tripp 1997) or deterred by the state (de Soto 1989), micro-enterprises have sustained Third World economies and in some cases kept them from collapse. De soto (1989) and others claim that states encourage the growth of the informal sector by imposing costly regulations that interferes with free enterprise (Weiss 1987; Portes and Benton 1984). These informal enterprises are not only self-created employment, but also provide affordable goods and services to persons who would otherwise not have access to them. Therefore, the extension of assistance to these informal micro-entrepreneurs may reflect development professionals' recognition of the economic contributions of these marginalized workers.

Another explanation for the support of micro-entrepreneurs, which deserves further exploration, is the recognition of the informal sector as a political constituency (Cross 1998, Tokman 1989). For example, because the autonomy and flexibility of their work allows for impromptu participation at political protests and events, micro-entrepreneurs such as street vendors are an attractive constituency to politicians. Micro-entrepreneurs may gain support from factions of the state in exchange for patronage (Cross 1998). Programs to assist micro- 
entrepreneurs could be connected to election year campaigns so that political interests may control the assistance micro-enterprise programs are provided.

Finally, some have pointed to the loosening of the World Bank and IMF agenda from strict neo-liberalism. The outcry at the increase and persistence of poverty and unemployment after more than a decade of structural adjustment policies has pressured the IMF and the World Bank to address these increasing inequalities (Walton and Ragin 1990). Currently, both these organizations formally support the expansion of micro-enterprises as a development strategy sponsoring meetings, forums, and focus groups on the topic.

While useful, these explanations for the expansion of micro-enterprise development still do not provide a deeper theoretical basis for understanding how informal micro-enterprises that once were depicted as a hindrance and then a failure of development have become a premier development solution. Limited explanation exists as to the historical conditions that lead to the emergence of micro-enterprise development in the mid-eighties or what informs its popular appeal.

\section{Globalization and the Double Duty of Unwaged Labor}

The analysis provided here marks the expansion of micro enterprise development as the transformation of the role of non-waged labor or household survival strategies in capitalist expansion and crisis. The failure of previous programs for economic advancement left policy makers to seek development or employment creation in household survival strategies that overwhelmingly are a response to these failures and the crisis of capitalism, generally. Below I show that assisting micro-entrepreneurs has come to serve as a form of social assistance replacing traditional government transfers. By limiting the avenues for governments and development agencies to provide social assistance or aid development, neo-liberalism plays a crucial role in sustaining the makeover of petty producers into micro-entrepreneurs and in recreating the role of household survival strategies in late capitalism.

The lack of early theorizing of micro-enterprises also is related to paradigms that neglect to conceive of women as economic actors. While Tinker (2000) and others working within the modernization paradigm argued for the incorporation of women into large scale industrial development, many feminists, working with a world-system orientation, challenged the gendered conception of work and quantitative labor force analyses that missed and dismissed women as primary income earners and their income earning strategies. Feminists have expressly elaborated the economic contributions that women made to households through their informal enterprises (Truelove 1990; Osirim 1992; Fernandez-Kelly and Garcia 1985).

Rosa Luxembourg (1913) illuminated first that women's unpaid reproductive work subsidizes the accumulation of capital. A theoretical Marxist, she argued that by overlooking the contribution of non-wage household labor the process of capitalist accumulation had been misestimated (Dunayevskaya 1991; Luxembourg 1913). Luxembourg (1913) explained that for capitalist accumulation to occur, a non-capitalist subsistence sector is necessary; in her analysis poorly paid industrial workers with their own economic endeavors could overcome the failure of capitalist enterprises to provide living wages and makeup for the state's limited response to human needs.

The world systems analysis of households (Wallerstein and Smith 1992a) further advances the structural role of subsistence work and petty production to the survival of the 
capitalist world system. Wallerstein and Smith explain that under global capitalism “ . . . the proletarian are condemned to remain partial wage workers ..." " and that ". . . in a capitalist world-system, wages can never be the sole or even principal mode of payment of the vast majority of the world workforce ..." (Wallerstein and Smith 1992b:254). Throughout the trajectory of capitalism households have relied on several means of meeting economic needs including rents, transfers, subsistence, and market transactions. Market transactions, including informal sector activity, increase and decrease depending on the state's capability of allaying the inequalities capitalism renders. As Wallerstein and Smith (1992b:258) explain:

In so far as the state and large corporation wish to eliminate or reduce the petty market operations for a variety of reasons (ranging from the elimination of competition to police control to the aesthetics of urban life) welfare is essential. In so far as there is a reduction in welfare, there must necessarily be a resurgence in petty market operations (including those that are formally illegal . . .).

With micro-enterprise development, households' abilities to shift between state welfare and petty market operations for making up income in households are less available. Expanding and assisting petty operations is a major form of social assistance in Trinidad and Tobago, throughout the Caribbean, and in much of the global south. As a strategy of economic development, the focus of micro-enterprise programs on petty market operations, subsistence or household survival strategies displaces the creation of formal employment; government and capital are relieved from the onus of providing employment and the burden placed on the poor and unemployed. Welfare or government transfers and petty market operations have merged into a single method for household to make up the limits to or absence of wages.

In other words, micro-enterprise development is a constitutive force of neo-liberal policies. Nations left with high rates of unemployment, increased poverty, and a decline in formal and government job opportunities under SAPs, offer up micro-enterprises as a way out of financially stricken circumstances. Micro-enterprise development is the fusion of two historical strategies to overcome capital's crisis-informal self-employment and government transfers. For many governments' in the global south as well as NGOs tied to international funding, supervising and supplementing micro-enterprise programs is the primary avenue for assisting the poor and unemployed. No longer can the poor and unemployed volley as easily between social programs and independent means of earning an income-both of which bolster the overarching system of capitalism, but also sustain lives.

\section{DATA AND METHODS}

\section{Grounded Theory}

The constant comparative method of data analysis documents emerging categories while coding data and making a comparison of codes both within and between categories. Although not a linear process this approach provides a method for the "systematic discovery of theory from the data of social research" (Strauss and Corbin 1990). While there is a course to completing grounded theory, guidelines for collecting and analyzing are flexible and offer a set of general principles 
and "heuristic devices rather than formulaic rules" (Charmaz 2:2006; Atkison, Coffey, and Delamont 2003). It requires the researcher to continuously sort through developed categories, integrate them, abandon them, refer back to data and return to the written text, demanding the researcher to be both flexible and reflexive (Glaser and Strauss 1967). Prior to the development of theoretical concepts and frames, themes are derived from an analysis of data that is typically collected by the researcher doing the analysis.

Although codes and themes regarding the expansion of micro-enterprise development began to emerge while I was still in the field, the deeper analysis began during transcription. I transcribed each interview verbatim and began noting the recurrent themes. During the final analytical stage that includes reviews of the transcribed interviews, field notes, and documents produced by the Trinidad and Tobago government ministries and the various micro-enterprise programs, I formalized the themes presented in the findings. These themes then lead to a conceptual frame for understanding the expansion of micro-enterprise development in Trinidad and Tobago that may (or not) apply to other nations.

\section{Data}

I made two separate research visits to Port of Spain, Trinidad; overall I spent 6 months in the field between summer 1998 and Spring 2001. The programs from which data were collected include all government-run and international programs, programs sponsored by credit unions and private banks, and larger religious based programs aimed at Trinidad's urban population. I did not interview participants in small religious based micro-enterprise program and three or four programs that focused on agriculture development.

I used various sources to identify Trinidad's micro-enterprise programs. An ILO publication (1998), the "National Directory: Organizations Working with Small and Micro Businesses, Special Focus on Women Entrepreneurs," provided a description and contact information for a number of the programs (the booklet includes both general micro-enterprise programs as well as programs accessible only to women) from which I collected data. The librarian at the Small Business Development Corporation (SBDC) helped with a list of all active micro-enterprise programs. It happened that during the period of my research the rise of microenterprise programs was rather acute so that I learned of several new programs by watching local televised news and reading the daily papers and during interviews.

I interviewed more than forty-five individuals who work or worked in various capacities in government ministries, international non-governmental organizations, private institutions, or local non-governmental organizations and were dedicated to micro-enterprise development. Many of the interview participants had worked in the development sector their entire work lives; over seventy five percent had more than a decade of work experience in the development. The majority of interviews (sixty percent) were conducted with state officials, a quarter was conducted with NGO representatives, and about fifteen percent took place with professionals in private institutions such as development banks. The distribution of interview participants is proportional to the distribution of the micro-enterprise development program type. In other words, the majority of programs are state-run, followed by non-governmental programs; more recently and, for the time being, least actively, private institutions are also engaging in microenterprise development. There are slightly more women than men in the interview pool, probably because women tend to direct and work the few women-centered micro-enterprise programs. 
Trinidad and Tobago is the most ethnically diverse nation in the Caribbean. African Trinidadians and Indian Trinidadians each makeup approximately 45 percent of the population; the remaining ten percent is made up of Whites, Chinese, and Lebanese/Syrians. Among the government workers or field officers interviewed, the majority are African-Trinidadians. An equal number of African-Trinidadians and Indian-Trinidadians government program leaders were interviewed. African-Trinidadians have historically participated at all levels of the state employment system, and the United National Congress (UNC), the Indian Trinidadian dominated party, that controlled government during my period of data collection, markedly increased IndianTrinidadian representation in higher-level government positions. Many of the workers and leaders of local non-governmental organizations I interviewed were African-Trinidadian women. For the most part micro-enterprise professionals in international organizations were not Trinidadians but citizens of other developing countries. ${ }^{5}$

Half of the interview participants were heads of programs--for instance vice-presidents, directors, or chief executive officers--who are responsible for the administration and direction of programs. A quarter of the interviews were conducted with heads of programs also active in the field, being directly involved with persons who sought program funds or training. Another quarter of the interviews was conducted with field workers, who, engaged in various aspects of micro-enterprise programs such as promotion or fundraising. They were primarily responsible for working with micro-entrepreneurs. When possible, I interviewed both heads and field officers of a program. Interviewing a range of actors in micro-enterprise development helped me gain a richer picture of why micro-enterprise development is so strongly advocated in Trinidad and the extent to which the state and other agencies that work in the interest of poor and low income have come to rely on it to meet the needs of their client population. I learned about everyday administrative problems and the practical concerns of addressing the needs of individual micro-entrepreneurs. Many of the interviews were conducted with persons who had been involved during the initiation of micro-enterprise programs to gain perspective on factors contributing to a program's inception.

Finally, I conducted interviews with high-ranking government officials in the Ministry of Trade, Ministry of Planning, Ministry of Gender, Ministry of Sports and Youth Affairs, and the Trinidad and Tobago Tourism and Industrial Development Company (TTIDCO), who are more broadly involved in the implementation of micro-enterprise development as a government economic policy. In addition, I spoke with NGO representatives from Working Women, the Network of Non-governmental Organizations for the Advancement of Women, and the Caribbean Association for Feminist Research and Action (CAFRA). These are organizations that address micro-enterprise development as part of their overall focus on the empowerment of women. I

\footnotetext{
${ }^{5}$ To maintain the anonymity of the interview participants, I do not provide the race and gender of participants or refer to specifically to the organizations they work in the methods or findings. To maintain the anonymity of the interview participants, I do not provide the race and gender of participants or refer specifically to the organizations they work together in the methods or findings. While I describe and present numerous characteristics of interview participants including race, gender, job status, place of employment, and years in service, they are intentionally disaggregated to preserve the anonymity. For the same reason I have not created a table. Trinidad and Tobago has a population of a little more than a million and its professional class, based on my own assessment and Trinidadian colleagues is small enough that participants possibly would be identifiably if two or more characteristics were provided together.
} 
also spoke with the micro-enterprise professional at the Inter-American Development Bank (IDB). Lastly, I spoke with sociologists and economists and regional development consultants. Along with conducting interviews, I reviewed government documents pertaining to microenterprise development in Trinidad. Many times the government officials with whom I met were kind enough to offer me copies of published and unpublished documents or at least to inform me of a document's existence and location. All in all, I reviewed approximately twenty-eight documents. Librarians of government Ministries were most resourceful in directing me to publications that related to my subject. Non-governmental organizations were also generous in providing me with access to their organization's policy statements and documents. Reading and summarizing these documents confirmed and supported my analysis of the expansion of microenterprise development in the Caribbean.

\section{THE RISE OF TRINIDAD'S MICROENTEPRISE PROGRAMS}

What induced the sudden increase in the number of Trinidad's micro-enterprise programs? In just ten years the nation jumped from one well-established program to more than fifteen substantial programs (many of which were instigated by the state) and a number of smaller programs. All of the micro-enterprise professionals I spoke with pointed to national economic difficulties when explaining what instigated the inception of their respective programs and microenterprise development generally. Limited foreign investment, structural adjustment programs, and the lack of employment opportunities dominated discussions on the relationship between micro enterprise development and the nation's economy in the mid-eighties.

The lack of foreign investment in the Caribbean beyond extractive industries is a visible failure of modernization. Although nations did their best to lure them, foreign capitalists never invested in local development in the Caribbean as Lewis had predicted. As a vice-president of government small business development agency explains:

Trinidad has not been able, I don't think any of the islands have been able to do it, have not been able to attract foreign investment. We try and encourage them to use our market access arrangement through various trade agreements, but that has not been very successful in terms of attracting foreign investment. You can't wait on the foreign investor, you have to do it internally, and generate the jobs and generate the employment opportunities from you own resources. And this is what we have been encouraging the Caribbean to adopt . . . We hadn't been moved from that principle previously, with oil boom in the late 1970s, early 1980s we had gone into large enterprises, multi million dollar type of things, and we had neglected the small business sector tremendously for the last ten fifteen years. So we felt that we needed to get to basics in terms of developing a strong small business sector, and using that, twofold, one to deal with the unemployment situation, and secondly, creating linkages with the bigger businesses.

The statement above reflects the recognition by many Trinidadian officials of the bias in the scale of early development projects. When foreign capital did come to the Caribbean, it was usually to 
gain profits from investing in the extraction of natural resources. To the extent that foreign investment was made in the petroleum sector, it did serve as a base for development in Trinidad and Tobago. Located seven miles off the coast of Venezuela, Trinidad and Tobago has access to the off shore petroleum reserves located in this geographical zone. The hike in oil prices in the early seventies created enough revenue for the nation to support infrastructure development and to initiate manufacturing and tourist sectors. When world petroleum prices began to decline in 1982 and take another dip in 1987, the nation lost much of the revenue it relied upon. The nation's attempts at economic diversification were too limited to absorb the financial losses in the petroleum sector. In addition, assuming future profits from petroleum, government leaders had borrowed largely to finance further development and build an international line of credit (World Bank 1995). By 1986 Trinidad and Tobago's debt had reached 891 million US dollars. Through the 1980s Trinidad and Tobago maintained a negative economic growth rate and the GDP per capita, \$6000 US in 1982, was halved by 1992 (World Bank 1995).

Trinidad's micro-enterprise programs come partly as a response to the lack of foreign investment in the region. Industrialization projects such as manufacturing plants that would create stable formal employment never materialized as a major sector of employment (Malaki 1996). Although Trinidad and Tobago has been able to secure foreign investment in its petroleum and natural gas industry, this sector employs just three percent of the population. As the leader of the state’s youth micro-enterprise training program admits:

I think that its not tough to recognize that big business is not in fact creating sufficient job opportunities to absorb all the school leavers and stuff. Entrepreneurship is being encouraged; micro-entrepreneurship is being encouraged. Again this is recognition-there is a limit to the creation of wage employment. You now have to find alternatives, and the alternative is, of course, entrepreneurship.

The modernization project failed to provide sufficient employment for Trinidadian workers and for a period economic growth came to a standstill (Griffin 1997). Guided by modernization thought, these development professionals focused mostly on the lack of foreign investment when explaining initial difficulties in labor and economy. Yet Lewis (1954) and others overlooked the necessity of subsistence, unwaged labor, or small flexible units of production for capitalism. The formalization of all workers into large-scale industrial production is a false principle of modernization that misled many post-colonial development strategies and resulted in large-scale debt.

\section{Unemployment and SAPS}

A lender to the IMF until 1984, the Republic of Trinidad and Tobago turned to the institution in 1988 to reschedule the debt it had incurred to international commercial banks. The IMF forced the nation to undergo a process of structural adjustment reforming the entire economy. Ushering in the age of neo-liberalism, free trade, and globalization, structural adjustment programs (SAPs), which were implemented throughout the Caribbean, are associated with the socio-economic descent of many Caribbean and Latin America countries. 
SAPs mandate the reduction of state expenditures on social programs. Between 1986 and 1992 Trinidad and Tobago's social expenditures declined by 47 percent, decreasing the quality and availability of health and education services to the general public (Theodore 1993). Government subsidies on basic food items for assisting the very poor were reduced or discontinued. In addition, to increase its revenue the government implemented a value-added tax (VAT), a fifteen percent tax on every item formally sold in the country. These changes raised the cost of basic living items and economically strained the low-income residents. By the end of the 1980s one of the most problematic changes in Trinidad and Tobago was the acute rise in income inequality (Development Cooperation 1996).

SAP programs also demand the reduction of the state employment role as well as the privatization of state controlled industries. State employment was the prime source of formal employment for African-Trinidadian workers. Between 1985 and 1989, government reduced its labor force by almost thirty thousand workers (Theodore 1993). Remaining state employees suffered a ten percent reduction in salary. The official unemployment rate doubled, reaching twenty-five percent. During the same period approximately 120,000 Trinidadians, or about ten percent of the population migrated to the US to seek employment (Economist Intelligence Unit 1998, World Bank 1995). Between 1982 and 1990, over ten thousand workers were recorded in government statistics to have entered informal self-employment (Theodore 1993). In the late 1980s over 35 percent of population was living below the poverty line (Ministry of Social and Community Development 1996).

With state employment restricted by IMF requirements and losses in the private sector, the government increasingly moved towards micro-enterprises as an employment creation solution. As a government official explains:

In what-'86? '87? - the unemployment rate reached probably 25\%, something like that. So the government felt that they needed things to stimulate, um, employment, particularly self-employment, to encourage a lot of people who had been retrenched and displaced from wage employment to get involved in activities.

A worker in the Ministry of Gender and Culture that runs the Second Chance program responding to my question, “ When did micro-enterprise development take off?” states:

I would think '87, '88, '89, when government felt that we couldn't employ, but maybe people who are going into their own enterprises would be able to make sustainable livelihoods for themselves. We had moderate recovery in the middle nineties, and you know, recovering from that recession, but the problem is we are having jobless growth. We had the recession from oil, and after that we went into structural adjustment and it meant that unemployment went up; it was in the twenties for both men and women.

Many micro-enterprise professionals pinned the spread of micro-enterprise development directly to the implementation of structural adjustment policies. For many government and development professionals self-employment or micro-businesses seems to present the only way out of unemployment. As the micro-enterprise official in the Ministry of Gender explained, 
“Trinidad may be experiencing economic growth, but it is jobless growth.” Although structural adjustment programs were to resolve the failure of past development strategies or as neo-liberals claim the excesses of the state, over a decade later many Trinidadians are economically stressed with difficulties in making ends meet and unable to find satisfactory employment.

Structural adjustment programs wiped out government transfers that both waged and nonwaged workers need and rely upon. The increase in the percentage of Trinidad and Tobago's workers who became informally self-employed after the implementation of SAPs demonstrates the inverse relationship between government transfers and petty market operations. What is unprecedented is the transformation of these survival strategies into programs of economic development. Caribbean households have historically relied on women's self generated income, yet in the past these strategies were considered a burden to economic development. Microenterprise development marks a novel transformation of how households are to survive under capitalism and the role of the state in their survival.

\section{Ideological Consistency}

Trinidad's micro-enterprise officials attribute the expansion of micro-enterprise development to the failure of past policies. Yet interviews revealed that ideological forces also play a central role in the expansion of micro-enterprise development. The two themes that developed across interviews, social safety net and profitability, suggest that micro-enterprise development is promoted because it can be construed as consistent with the principles of neo-liberalism. As private enterprises that compete in the global marketplace, micro-enterprises serve as a marketdriven solution to the social and economic problems faced by the global south.

\section{A Safety Net Under Globalization}

With limits on state employment, the removal of state subsidies, and an ending of government regulation, micro-enterprise professionals and development workers identify micro-enterprise development as a workable strategy to address poverty and unemployment. A young worker in the Ministry of Social \& Community Development provides an excellent summary:

It is the way the whole country is moving, . . . you know you saw, and not just here, it was kind of a world wide thing away from the welfare state, ok well you know the whole paradigm shift away from being just a welfare state, free market kind of thing. So as oppose to we are just going to give hand outs, we want people to start to do things. So if I give you some money I expect that, you know you are going to get into some business, and make it sustainable, so I am going to help you out, but I expect that you will maintain the business, sustainability, right? And in that, of course, so I've helped you and then you in turn because you have your little business, all your linkages right? So you are going to employ two people, and those two people will be able to send their children to school, so that we are going down the road right, all the social support, you could see it. You could see it, right? 


\section{JOURNAL OF WORLD-SYSTEMS RESEARCH}

One of the underlying assumptions of the current promotion of micro-enterprise development is that the poor and low-income can create their own means of economic survival rather than choosing to depend on government transfers. Along with recognizing macro-economic failures, micro-enterprise professionals follow neo-liberal analysis and primarily blame state created dependency for the nation's poverty and unemployment. The director of a womencentered government micro-enterprise program describes the culture of dependency as a "gimmegimme syndrome." Neglecting the historic use of self-employment by Caribbean women, he like other professionals identify micro-enterprise development as a vehicle for ending "dependency" and a route for economic security for the poor and low income in the era of globalization. Administrators of micro-enterprise programs repeatedly referred to their programs as offering a different kind of social safety that is needed in the context of globalization. A UNDP official explains the relationship between globalization and micro enterprises:

The relationship I can best look at is the social safety net. This government has a policy of a social safety net for the less fortunate in our community. This government is promoting micro credit program as part of catching the fall out of globalization if you like, or addressing the ones that might fall through. By helping people build opportunities and livelihoods where they do not depend on the state or charity for their existence.

Although micro-enterprise professionals accept the critique of state dependency and the logic of neo-liberalism, their experience in the field also leads them to conclude that the economically distressed require some form of assistance or safety net. They may also be influenced by the legacy of social programs that the Trinidad and Tobago government had promoted even during colonialism. A regional ILO officer describes the shifts in employment and social strategies in the Caribbean islands. He further elaborates the relationship between globalization and the advance of micro-enterprise development:

Some years ago they didn't need anything other than strict employment, took care of thirty years in one place, the salary was sure, all the benefits was there, and that was it. So you didn't need to strain yourself, so the need to strain came with difficulties at the international level, all right, so then the need to now look for alternative, that is what drives the micro. The emphasis has been providing a safety net under globalization that has been the major goal. Most Small Enterprise Development Units (SEDUs), are for example from the early 1990s, that's why it's really a response to globalization.

Globalization is at once a set of economic circumstances and a set of biases on how to respond to these circumstances. Although post-colonial states have always been constrained in development choices (Evans 1979), the structural adjustment policies many of these nations have agreed to further diminish their ability to offer secure employment and traditional forms of social assistance. Many of the professionals I interviewed, who have worked for years in the field of development, continually pivot around the various requirements of national and international bodies and policies to create development. Currently, micro-enterprise programs provide one of the only avenues for development actors to remain ideologically consistent with neo-liberalism 
and circumvent international criticism to remain players in the global marketplace while attempting to address poverty and unemployment.

Yet by doing so, micro-enterprise professionals conflate social assistance with petty market operations. In effect, relying on micro-entrepreneurs to create and sustain employment begins to relinquish the state from subsidizing capitalism via transfers to households. Although micro-enterprise programs may provide some kind of assistance, the burden of making up capitalism's wages shortfall is placed on the exploitation and self-exploitation of microentrepreneurs.

\section{Sustainability and Profitability}

The acceptance of neo-liberal principles for solving unemployment and creating economic development has also altered the principles of development organizations that were once comfortable providing social assistance. As this statement made by a UNDP official leading the agency's micro-enterprise program in Trinidad expresses:

Bottom line this is business, and as much as you could have the social agenda and the environmental agenda and whatever, when it comes to business activity, there are business principles. That has nothing do to with your understanding about development or anything, that is straight business, and that is in a sense the value system, that the sort of commercial world has taught us, an economic point.

The UNDP has formally and consciously changed their mission. Rather than presenting themselves as an aid agency, they now ascribe to a program of sustainable development. That is development that can be sustained without financial contributions and without government involvement in redistributing national economic gains. Development agencies and governments have recast petty producers as the most micro units of neo-liberalism. Under this guise they warrant assistance because they are perceived to be seeking sustainability and profitability.

In addition, changes in technology and in laws over moveable property rights have made small loans lucrative for large banks. Neo-liberal reformers find micro-enterprises attractive not only because they seem to exercise business principles but also because they offer a new area for capital investment. Private banks and international financial institutions are moving into microenterprise development or micro-finance to make gains on the interest on loans provided to the poor and low-income to develop enterprises. As the micro-finance director in a development bank explains:

We are a private institution and we will make money, we are not in this for charity ok. We are not an NGO. So we are into sustainability up front, not charity, most of international organizations now are saying hey stop giving away money, its not a limitless supply, we need to start seeing some return, we need to start seeing people get profitable. Give away money has limited entrepreneurship to an extent; so, you see give away money is fine for charity. Give away money is not for entrepreneurs and when we give money away toward our entrepreneurs we kill their drive to fight, and so I think that has been actually an impediment to entrepreneurship, not just in Trinidad but also in the Caribbean. 
The sharp critique of NGOs performance in assisting micro-entrepreneurs offered above reveals the claim that private banks and interests are moving in on a sector they previously rejected as unprofitable or had no means of making lucrative. Up until the last decade, the private sector showed little interest in micro-enterprise development. Loans to micro-entrepreneurs were considered risky, with high administrative costs and limited profitability, and thus beyond the scope of commercial banks.

Self-employment has been so widely practiced in the Caribbean and a major means of household survival that NGOs offering assistance could hardly impede the success of these enterprises. A more important issue, and one that needs more comprehensive study, is understanding whether and how they have assisted micro-entrepreneurs. Rather than being appreciated as harbingers of the current expansion of micro-enterprise development, NGOs are critiqued for interfering with business development. As a leading IDB official working with the government to change legal codes over moveable property rights states:

I find that its a lot easier to get a financial institution to become a little bit more like an NGO than it is to get an NGO to become more like a bank. You know, all these NGOs will tell you how successful they are, but if you get in there and you really look at their books you find there are huge gaps. I think if you are dealing with an NGO who has a social welfare focus, too many cases they require a subsidy to exist, and that is not what the micro-entrepreneurs need long term. You need an organization that is going to stay around and I think the commercial banks will be around a lot longer than the NGO.

Whereas self generated income earning projects serve households as a method for making up the limits of wages when the state could not or would not, in the current era they also provide a way for governments and development agencies to delegate social assistance and are fast becoming an arena for capitalist accumulation. The new profitability of micro lending helps drive the expansion of micro-enterprise development because it affirms neo-liberalism.

The fundamental argument made by micro-enterprise professionals in private or financial enterprises is that micro-lending agencies assist micro-entrepreneurs best when they profit or at least maintain sustainability from the loans they provide. Of course, such a claim requires further empirical assessment, but the belief in such an argument elucidates the misunderstood role of the small informal enterprises that these institutions target. Micro enterprises historically are created when the state does not provide sufficient transfers and because the private sector does not offer sufficient formal employment or wages.

Not all micro-enterprise professionals advocate profit as the organizing principle of their agencies, but they do acknowledge the pressure of neo-liberal reforms. A lending consultant from one of Trinidad's older micro-enterprise program explains, "We realize that we may have to operate like a financial institution, so that means that it's going to put you very close in line to operating like a bank, and this is something the founders are trying to shy away from." Even agencies with the high goal of mitigating poverty must couch the assistance they offer micro entrepreneurs in neo-liberal terms to garner sufficient support for their program. 


\section{MICRO-ENTERPRISE DEVELOPMENT AND THE CRISIS IN CAPITALISM}

The awarding of the 2006 Nobel Peace Prize to the Grameen Bank and Yunus Muhammad, a pioneer of microfinance and the bank, suggests that micro-enterprise development has reached considerable popularity for resolving a host of economic and now social problems in the global south. That micro-enterprise development has carried over from the "developing world" to developed contexts-presently there are over 400 programs situated in poor and low-income communities in the US - reflects its acceptance as a panacea for poverty and unemployment everywhere (Schreiner and Woller 2003; Ehlers and Main 1998; Rodriguez 1995). With the current tumult of the global economic crisis and worldwide loss of employment opportunities, micro-enterprises are sure to remain an attractive solution. ${ }^{6}$

While micro-enterprise development is internationally promoted as a way to solve poverty and unemployment for post-colonial nations, it is an especially attractive policy for the Republic of Trinidad and Tobago. A small island nation, Trinidad and Tobago has difficulty drawing foreign investments outside the capital-intensive energy sector and creating sufficient employment opportunities. Previously neglected for larger industrial projects, micro-enterprises are depended upon by many government officials for diversifying the economy and creating job growth at the rate of four percent per annum.

Although Trinidad implemented the recommended policies of modernization, the traditional sector materialized as an urban phenomenon as it did across the globe (Roberts 1978). The inability of the formal sector to absorb workers depleted Lewis's argument that developing economies would reach a turning point of labor supply that would lead to higher incomes and greater equality. The evidence was on the streets; individuals, families, and children were selling services, produce and products to make a livelihood. In almost every post-colonial city, households were turning their homes into production units and business facilities creating their own means of employment. Challenging modernization, de Soto (1989) demonstrated that the urban informal sector was a buttress to national economic development, drawing the attention of Latin American policymakers to the economic utility of micro-enterprises.

No longer discarded as survival strategies and least of all admonished for hindering development, informal petty producers are lauded as model citizens (Itzgsohn 2000). The new perspective on the role of micro-entrepreneurs in national economic development and support for their assistance coincides with the downward spin of the global south economies in the 1980s; in 1985 GNP's dropped throughout the world. This crisis of global capitalism lead to a series of policy changes; market principles were prioritized and the state removed from economic development.

A foundational tenant of neo liberalism, the rhetoric around the efficiency and effectiveness of the private sector buttresses arguments that government programs created state dependency and hindered entrepreneurialism—a sentiment consistent with the neo-liberal thought globally. Yet claims of dependency and limited entrepreneurship overlook the legacy of microenterprises or petty trade and production in the Caribbean - rather than turning to a state that may or may not provide the needed assistance, households create their own sources of income.

Government officials and development professionals characterize micro-enterprises, formal or informal, no matter the size or activity, as examples of entrepreneurialism and private

\footnotetext{
${ }^{6}$ In June 2009 Kiva.org, one of the largest on=line micro-lending agencies that serves global south countries started offering loans in the US.
} 


\section{JOURNAL OF WORLD-SYSTEMS RESEARCH}

initiatives. In essence, petty producers are now the foot soldiers of neo-liberalism. Yet referring back to the work of Luxembourg (1913) and Wallerstein and Smith (1992a, 1992b), unwaged labor has always been essential for the expansion of capitalism. Although modernization proponents such as Lewis imagined the disappearance of the traditional sector or labor outside large scale industry, they miscalculated not only the inability of this sector to absorb all potential laborers but also that the system of capitalism requires labor in the non-capitalist spheres to retain its elasticity and stability (Cliff 1969).

The conjecture of structural, ideological, and technological conditions documented in this study created a context in which micro-enterprises appears as a promising solution to the failures of past development policies. The current indebtedness of post-colonial nations or the "third world debt crisis" can largely be attributed to national borrowing encouraged by modernizations proponents, like Lewis, and many development scholars and practitioners in the US during the late fifties and sixties. In a somewhat ironic twist a solution to the current poverty and unemployment of the global south, that SAPs and past borrowing have helped to create, is more borrowing - but this time by individuals and households of the global south rather than nations. The expansion of micro-enterprise development demonstrates an increased reliance on unwaged or non-formal labor to make up the shortfall of formal sector wages in the world-system. Microenterprise development gives new meaning to the declaration that "the proletarian are condemned to remain partial wage workers” (Wallerstein and Smith 1992b).

Finally, the distribution of micro-credit is fast becoming another way for international financial institutions to profit from workers in the Caribbean and beyond. With an increasing portion (possibly the majority) of Caribbean workers involved in employment outside the waged formal sector, micro-credit is a mechanism through which international capitalists can make economic gains from self-employed workers. By offering credit, international finance agencies profit from the interest on loans made to micro-entrepreneurs. Even in our weak economic environment, micro-lending is considered a stable investment opportunity (Littlefield 2008). This new relationship between banks and petty producers demonstrates the very strong case Luxembourg (1913) makes against Marx's oversight of the non-capitalist sphere, in essence that capitalism depends on the existence of non-capitalist (informal and non-waged) formation into which it can expand (Cliff 1959).

International reliance on self-created employment seems to misdirect the attention of states and development agencies from creating employment opportunities that offer security, regulated labor conditions and wages, and social benefits such as retirement plans and maternity leave (Scully 1997). Future research is needed to determine if micro enterprise programs actually increase economic opportunity or place the burden of employment creation on the unemployed and the marginalized themselves. The "little businesses" unemployed or underemployed workers create must compete with international capital, as well as negotiate the ebbs and flows of the global economy. As the current centerpiece to international development, more research needs to be conducted exploring how assisting micro enterprises or earnings outside the formal labor market can be made into a systematic and long term solution to poverty and unemployment. Under what conditions can micro-enterprises sustain secure livelihoods rather than remain a knee jerk response to the failures of modernization?

Our current moment breathes new interest in development policy especially those that target unemployment. Can the current crisis be bandaged with programs that result from capitalist favoring ideologies or have we reached a more critical state? Will the conceptual framework 
developed here, in which two methods of surviving capitalism merge into a single outlet, be repeated elsewhere and workers even further burdened with a crisis they did not create? We are hinged on a new age in development-the relationship of global and national economic policy, unemployment, and micro-enterprise should garner some interest.

\section{ACKNOWLEDGEMENTS}

Receipt of the fellowship awarded by the American Association of University Women contributed to the development of this manuscript. Comments by Joya Misra, Linda Grant, Ivy Kennelly, Cynthia Hewitt, Arthur Kastler, Micheal Hodge, and E.M. Beck on earlier versions of this research helped develop the argument presented here. I am most indebted to the contributions of interview participants who gave their time willingly sharing their thoughts and knowledge. Thanks also to the editors and blind reviewers of JWSR for their careful reading and comments.

\section{REFERENCES}

Atkison, Paul, Coffey, Amanda and Delamont, Sara. 2003. Key Themes in Qualitative Research. AltaMira Press.

Barrow, Christine.1986. Finding the Support: A Study of Strategies for Survival.' Social and Economic Studies 35:131-163.

Bollen, Kenneth. 1983. "World System Position, Dependency, and Democracy: The CrossNational Evidence.” American Sociological Review 48:468-479.

Bradshaw, York W. 1988. "Reassessing Economic Dependency and Uneven Development: The Kenyan Experience.” American Sociological Review 53:693-708. 1987. "Urbanization and Underdevelopment: A Global Study of Modernization, Urban Bias, and Economic Dependence.” American Sociological Review 52:224-239.

Castells, Manuel and Alejandro Portes. 1988. "World Underneath: The Origins, Dynamics, and Effects of the Informal Economy." Pp. 11-40 in The Informal Economy, Studies in Advanced and Less Developed Countries, edited by A. Portes, M. Castells, and L.A. Benton. Baltimore and London: Johns Hopkins University Press.

Charmaz, Kathy. 2006. Constructing Grounded Theory: A Practical Guide through Qualitative Analysis. London, Sage.

Corbin, J. and A. L. Strauss.1990. Basics of Qualitative Research: Grounded Theory Procedures and Techniques. Newbury Park, Calif.: Sage Publications.

Cross, John.1998. Informal Politics: Street Vendors and the State in Mexico City. CA: Stanford University Press.

Davis, Mike. 2006. Planet of Slums. Verso.

de Soto, Hernado. 1989. The Other Path: The Invisible Revolution in the Third World. Harper and Row.

Development Co-Operation Report.1996. Republic of Trinidad and Tobago.

Dignard, Louise and Jose Havet.1995. Women in Micro-and Small Scale Enterprise Development. Boulder: CO: Westview Press. 
Dixon, William J. and Terry Boswell. 1996. "Dependency, Disarticulation, and Denominator Effects: Another Look at Foreign Capital Penetration." The American Journal of Sociology 103:2:543-562.

Dookeran. 1996. Choices and Change Reflection on The Caribbean. Inter-American Development Bank.

The Economist Intelligence Unit. 1997-1998. Country Profile: Trinidad and Tobago, Surinam, Netherlands, Antilles, Aruba. London: The Economist Intelligence Unit.

Ehlers, Tracy Bachrach and Karen Main. (1998) 'Women and the False Promise of Microenterprise Development' Gender and Society 12:424-440.

Evans, Peter B. 1979. Dependent Development. Princeton, New Jersey: Princeton University Press.

Fernandez-Kelly, Patricia M., and Anna M. Garcia. 1985. "The Making of an Underground Economy: Hispanic Women, Home Work, and The Advanced Capitalist State.” Urban Anthropology 14:59-90.

Firebaugh, Glenn. 1996. "Does Foreign Capital Harm Poor Nations? New Estimates Based Dixon and Boswel's Measures of Capital Penetration.” The American Journal of Sociology.” 102:2:563-575.

Fiss, Peer C. and Paul M Hirsch. 2005. "The Discourse of Globalization: Framing and Sensemaking of an Emerging Concept.” American Sociological Review 70:29-52.

Freeman, Carla. 2000. High Tech and High Heel in the Global Economy: Women, Work, and Pink-Collar Identities. Durham, NC: Duke University Press.

Geertz, Clifford. 1963. Peddlers and Princes, Social Change and Economic Modernization in Two Indonesian Towns. Chicago: University of Chicago Press.

Girvan, Norman.1997. Poverty Empowerment and Social Development in the Caribbean. University Press of West Indies.

Glaser, Barney G. and Anselm L. Strauss. (1967) The Discovery Of Grounded Theory: Strategies for Qualitative Research. New York: Aldine de Gruyer.

Grasmuck, Sherri and Rosario Espinal. 2000. " Market Success or Female Autonomy? Income, Ideology, and Empowerment among Microentrepreneurs in the Dominican Republic.” Gender and Society 14:231-255.

Griffin, Clifford E. 1997. Democracy and Neoliberalism in the Developing World: Lessons from the Anglophone Caribbean. Brookfield VT: Ashgate Publishing.

Grosh, Barbara and Gloria Somolekae. 1996. 'Mighty Oaks from Little Acorns: Can Microenterprise Serve as the Seedbed of Industrialization?' World Development 24: 1879-1890.

Gulli, Hege and Marguerite Berger. 1999. "Microfinance and Poverty Reduction-Evidence from Latin America." Small Enterprise Development 10:16-28.

Harrison, Faye V. 1991. “Women in Jamaica’s Urban Informal Economy.” Pp. 173-196 in Third World Women and the Politics of Feminism, edited by C. Mohanty, A. Russo, and L. Torres. Bloomington, IN: Indiana University Press.

Hsiung, Ping-Chun. 1996. Living Rooms as Factories: Class, Gender, and the Satellite Factor System in Taiwan. Philadelphia: Temple.

International Labour Organization. 1998. Report on the Follow-Up Workshop on Women Entrepreneurs in Micro and Small Businesses in Trinidad and Tobago. St. Joseph, Trinidad: ILO publications. 
1995. Small Businesses: Key Ingredients and Constraints to Their Success in the Caribbean. Port of Spain, Trinidad.

Isserles, Robin G. 2003. "Microcredit: The Rhetoric of Empowerment, the Reality of Development as Usual.” Women's Studies Quarterly. 31:38-57.

Itzigsohn, John. 2000. Developing Poverty: The State, Labor Market Deregulation, and the Informal Economy in Costa Rica and the Dominican Republic. The Pennsylvania State University Press: University Park, Pennsylvania.

Johnson, Susan and Thalia Kidder. 1999. "Globalization and Gender-Dilemmas for Microfinance Organizations.” Small Enterprise Development 10: 4-15.

Jurick, Nancy. 2005. Bootstrap Dreams: US Microenterprise Development in an Era of Welfare Reform. Ithaca, NY: Cornell University Press.

Kantor, Paula. 2002. "A Sectoral Approach to the Study of Gender Constraints on Economic Opportunities in the Informal Sector in India.” Gender and Society 16:285-302.

Keily, Ray 1998. "The Crisis of Global Development.” Pp. 24-44 in Globalization and the Third World, edited by R. Kiely and P. Marfleet. London: Routledge.

Kentor, Jeffrey. 1981. "Structural Determinants of Peripheral Urbanization: The Effects of International Dependence.” American Sociological Review 46:201-211.

Kenworthy, Lane. 1995. In Search of National Economic Success: Balancing Competition and Cooperation. Thousand Oaks, CA: Sage Publications.

Klak, Thomas. 1999. "The Underdevelopment of the Caribbean and its Scholarship.” Latin American Research Review. 34:209.

Klak, Thomas and Dennis Conway. 1998. "From Neoliberalism to Sustainable Development." Pp. 257-277 in Globalization and Neoliberalism: The Caribbean Context, edited T. Klak. Lanham, MD: Rowman and Littlefield Publishers, Inc.

Korzeniewicz, Robert Patricio and Timothy Patrick Moran. 1997. "World-Economic Trends in the Distribution of Income, 1965-1992.” The American Journal of Sociology 88:135-160.

Lewis, Arthur. 1954. "Economic Development with Unlimited Supplies of Labour." The Manchester School of Economics and Social Studies (May).

Light, Donald W. 2004. "From Migrant Enclaves to Mainstream: Reconceptualizing Informal Economic Behavior.” Theory and Society 33:705-737.

Littlefield, Elizabeth. 2008. "Microfinance and the Financial Crises." http://crisistalk.worldbank.org/2008/11/microfinance-an.html

London, Bruce and David A. Smith. 1988. "Urban Bias, Dependence, and Economic Stagnation in Noncore Nations.” American Sociological Review 53:454-463.

Luxemburg, Rosa. 1951. The Accumulation of Capital. London: Routledge \& Kegan Paul.

Malaki, Akhil. 1996. Development Patterns in the Commonwealth Caribbean: Jamaica and Trinidad and Tobago. Institute of Latin American Studies, Stockholm University.

Mattera, Philip.1985. Off the Books: The Emergence of the Underground Economy. NY: St. Martin's Press.

McBain, Helen. 2005. “Challenges to Caribbean Economics in the Era of Globalization.” Pp. 1742 in Contemporary Caribbean Cultures and Societies in Global Context edited by Franklin W. Knight and Teresita Martinez-Vergne. Chapel Hill: The University of North Carolina Press.

McMichael, P. 1996. 'Globalization: Myths and Realities.’ Rural Sociology 61:1. 
Mies, Maria. 1986. Patriarchy and Accumulation on a World Scale: Women in the International Division of Labor. London: Zed Books.

The Ministry of Social Development. 1996. The Determination and Measurement of Poverty in Trinidad and Tobago. Ministry of Social Development: Republic of Trinidad and Tobago.

Morduch, Jonathon. 2000. 'The Microfinance Schism.’ World Development 228:617-629.

Mosley, P. and D. Hulme. (1998). 'Microenterprise Finance: Is There a Conflict Between Growth and Poverty Alleviation?' World Development 26: 783-790.

Muller, Edward N. 1989. “Democracy and Inequality.” American Sociological Review 54:868871.

1988. Democracy, Economic Development, and Income Inquality.” American Sociological Review 53:50-68.

Nash, June. 1990. "Latin American Women in the World Capitalist Crisis.” Gender and Society 4: 338-353.

Nielson, Francois and Arthur S. Alderson. 1995. "Income Inquality, Development, And Dualism: Results form an Unbalanced Cross-National Panel.” American Sociological Review 60:674-701.

Peacock, Walter G., Hoover, Greg A., and Charles D. Killian. 1988. “ Divergence and convergence in International Development: A Decomposition Analysis of Inequality in the World System.” American Sociological Review 53:838-852.

Portes, Alejandro. 1997. 'Neo-liberalism and the Sociology of Development: Emerging Trends and Unanticipated Facts.' Population and Development Review 23: 2-25.

Portes, Alejandro and Lauren Benton. 1983. "The Urban Informal Sector: Definition, Controversy and Relations to Development." Review 7:151-174. .1984. "Industrial Development and Labor Absorption: A

Reinterpretation." Population and Development Review 10:586-611.

Portes, Alejandor, Carlos Dore-Cabral, and Patricia Landolt. 1997. The Urban Caribbean: Transition to the New Global Economy. Baltimore: Johns Hopkins University Press.

Portes, Alejandro, Guarnizo, Luis Eduardo, and William J. Haller. 2002. "Transnational Entrepreneurs: An Alternative Form of Immigrant Economic Adaptation.” American Sociological Review 67:278-298.

Portes, Alejandro and Saskia Sassen-Koob. 1987. "Making it Underground: Comparative Material on the Informal Sector in Western Market Economies. American Journal of Sociology 93:30-61.

Poster, Winifred and Zakia Salime. 2000. 'The Limits of Microcredit: Transnational Feminism and USAID Activities in the United States and Morocco', in N.A. Naples and M.Desai (eds) Women's Activism and Globalization: Linking Local Struggles and Transnational Politics, pp. 189-219. New York and London: Routledge.

Prugle, Elizabeth and Irene Tinker. 1997. 'Micro-entrepreneurs and Homeworkers: Convergent Categories', World Development 25: 1471-1482.

Roberts, Bryan. 1978. Cities of Peasants: The Political Economy of Urbanization in the Third World. Edward Arnold: London

Rakowski, Cathy. (1994) Contrapunto: The Informal Sector Debate Latin American Perspectives. New York: State University of New York Press.

Reddock, R. E. (1994) Women, Labor and Politics in Trinidad and Tobago. London: Zed Books. 
Rodriguez, Cheryle Rene. (1995) Women, Microenterprise, and the Politics of Self-Help. New York: Garland Publishers.

Scully, Nan Dawkins. (1997) Microcredit No Panacea for Poor Women. //http: www/igc.org.dgap Schreiner, Mark and Gary Woller. 2003. "Microenterprise Development Programs in the United States and in the Developing World.” World Development 31:1567-1580.

Smith, David A. 1996. Third World Cities in Global Perspective: The Political Economy of Uneven Urbanization. Boulder, CO: Westview Press.

Stack. 1978. "The Effect of Direct Government Involvement in the Economy on the Degree of Income Inequality: A Cross-National Study.” American Sociological Review 43:880-888.

Strauss, Anselm L. and Juliet Corbin.1990. Basics of Qualitative Research: Grounded Theory Procedures and Techniques. Newbury Park, Calif.: Sage Publications.

Theodore, Karl. 1993. “An Overview of Social Sector Conditions in Trinidad and Tobago.” Republic of Trinidad and Tobago: University of West Indies

Timberlake, Michael and Jeffrey Kentor. 1983. "Economic Dependence, Overurbanization, and Economic Growth: A Study of Less Developed Countries." The Sociological Quarterly 24: 489-507.

Tokman. 1992. Beyond Regulation: The Informal Economy in Latin America. Lynne Rienner Publishers.

Tripp, Ali Mari. 1997. Changing the Rules: The Politics of Liberalization and the Urban Informal Economy in Tanzia. Berkeley, CA: University of California Press.

Truelove, Cynthia. 1990. "Disguised Industrial Proletarians in Rural Latin American: Women's Informal Sector Factory Work and the Social reproduction of coffee Farm Labor in Columbia.” Pp. 48-63 in Women Workers and Global Restructuring, edited by K. Ward. Ithaca, NY: Cornell University Press.

Waldinger, Roger and Michael Lapp. 1993. "Back to the sweatshop or ahead to the informal sector?" International Journal of Urban and Regional Research. 60:79-104.

Wallerstein, Immanuel and Joan Smith. 1984a. "Households as an Institution of the WorldEconomy." Pp. 3-23 in Households and the World Economy edited by J. Smith, I. Wallerstein, and H. Evers. Newbury Park: Sage Publications.

. 1984b. "Core-periphery and Household Structures" Pp. 253-262 in Households and the World Economy edited by J. Smith, I. Wallerstein, and H. Evers. Newbury Park: Sage Publications.

Walton, John and Charles Ragin. 1990. "Global and National Sources of Political Protest: Third World Responses to the Debt Crisis." American Sociological Review 55:876-890.

Weiss. Linda. 1987. "Explaining the Underground Economy: State and Social Structure." British Journal of Sociology 33:216-234.

World Bank. 1995. "Trinidad and Tobago: Poverty and Unemployment in an Oil Based Economy.” Report Number 14382-TR. 